\title{
Implementation of Microteaching in Special Teaching Methods I And II Courses: An Action Research
}

\author{
Ayşe Feray Özbal ${ }^{1}$ \\ ${ }^{1}$ Physical Education and Sport, Kastamonu University, Kastamonu, Turkey \\ Correspondence: Ayşe Feray Özbal, Physical Education and Sport, Kastamonu University, Kastamonu, Turkey.
}

Received: May 28, 2019

doi:10.5539/ies.v12n10p89
Accepted: August 6, 2019 Online Published: September 29, 2019

URL: https://doi.org/10.5539/ies.v12n10p89

\begin{abstract}
The aim of this study is to implement micro teaching method in Special Teaching Methods I and II courses in order to teach preservice teachers how to make lesson plans and help them gain experiences in classroom management issues; i.e. to improve their teaching skills. The study was designed according to the principles of action research. Pre-service teachers carried out micro teaching sessions during the fall and the spring term as a requirement of Special Teaching Methods I and II courses. The research process started at the beginning of each term. In the first 7 weeks, the instructor provided preservice teachers with theoretical knowledge about special teaching methods. The practice phase started after the mid-term exams, in which the participants were divided into groups and taught lessons on predetermined topics by using micro teaching methods. The teaching practices were video recorded. The data of the study were obtained from video recordings of the micro teaching sessions, the semi-structured interviews conducted with the participants and the learner diaries. A total of 40 preservice teachers participated in the study; however, the data from 10 participants were used in the analysis. The results revealed that preservice teachers gained experience in teaching and improved their teaching, classroom management, and lesson plan preparation skills thanks to this implementation.
\end{abstract}

Keywords: micro teaching, action research, special education methods

\section{Introduction}

Rapidly advancing technology has led to noticeable changes in many fields including "education". It is believed that the attempts to design and implement more quality educational practices in classrooms will contribute to the training of more successful generations in near future. Therefore, it is important to increase the quality of teacher training programs at universities. There have been many attempts to achieve this goal, and one of them is micro teaching method.

Learning to teach is a complex endeavor (Fernandez, 2012). Different methods have recently been used to eliminate this complexity. One of these methods is micro teaching method. Micro teaching method, which was developed in 1960s by Dwight W. Allen and his colleagues (Marulcu \& Dedetürk, 2014), has been often used in many current studies focusing on teacher education (Peker, 2009; Küçükoğlu et al., 2012; Arsal, 2014). Quinn (2000) defines micro teaching as an activity carried out with small groups of learners to help them gain certain skills effectively while Higgins and Nicholl (2003) suggests that it is about video recordings of micro skills performances (cited in Çoban, 2015). In addition, micro teaching method aims to simplify challenging learning and teaching processes as much as possible (Bilen, 2014). Moreover, it provides pre-service teachers with various opportunities to plan and implement new teaching strategies. In short, microteaching focuses on teacher behaviors (Gürses et al., 2005). Important to microteaching is the process of self-reflection (Mergler \& Tangen, 2010). This situation is important for the development of pre-service teachers. Thanks to the integration of micro teaching into teacher training programs, preservice teachers are provided with instant feedback about their teaching and content, and they are given the opportunity to be aware of and correct their mistakes and develop skills they lack and improve inadequate ones. At the same time, micro teaching method is a teaching practice used in improving teaching skills of preservice teachers. Actually, this practice is a reduced version of real classroom practices in terms of the number of students, the topic covered, skills and duration (Erciyeş, 2009). This method aims to determine strengths and weaknesses of preservice teachers and improve their teaching skills accordingly. Here, a preservice teacher teaches a lesson for a shorter time, and supervisor observes him without intervening and takes notes. At the end of lesson, supervisor and preservice teacher have a short conversation about his teaching practice 
(Karataş \& Cengiz, 2016). In other words, he has the opportunity to practice his teaching skills, realize his mistakes and inadequacies, revise lesson plans and improve themselves. The aim of micro teaching is to equip preservice teachers with various skills.

Taşpınar (2017) lists some skills that might be practiced by using micro teaching method as follows:

- Introduction to the lesson

- Teaching a concept or principle

- Teacher questioning

- Use of course materials and educational tools

- Wrap up and closure

Theoretical pedagogical formation courses offered in undergraduate programs for preservice teachers are effective in equipping them with necessary skills and providing field-related knowledge. However, when preservice teachers cannot find opportunities for practice, they often face difficulties while teaching in real classrooms and have to rely on trial-and-error method. Therefore, it is crucial to develop their teaching skills before they are employed as real teachers at schools.

Erciyeș (2009) lists the following issues that should be considered carefully in micro teaching method.

- It should be used to develop professional skills of preservice teachers before they are employed in real schools.

- It is necessary to plan lessons carefully and efficiently in terms of content and duration.

- It is necessary to benefit from technology so that preservice teachers can watch and evaluate themselves.

The literature about micro teaching method includes many studies focusing on primary school teaching, pre-school teaching, science, chemistry, mathematics and biology teaching (Çakır, 2000; Akyüz, 2014; Küçükoğlu et al., 2012; Karadağ \& Akkaya, 2013; Atav et al., 2014; Marulcu \& Dedetürk, 2014; Bilen, 2014; Karataş \& Cengiz, 2016). Providing future teachers of Turkey with quality teacher education is crucial so that teachers can contribute to the well-being of the country. To achieve this purpose, preservice teachers should be given opportunities to practice their teaching skills and improve themselves with proper guidance in addition to the theoretical courses offered by expert instructors. In this study, preservice teachers of physical education and sports were given opportunities to practice their teaching skills in Special Teaching Methods I and II courses. The most important objective of this study is to increase awareness of physical education and sports preservice teachers' about the importance of doing practices and to conclude that this practice will contribute to their self-development. Thanks to this practice, preservice teachers will gain insights about teaching and practice and become better teachers equipped with necessary skills for their professional life.

\section{Method}

\subsection{Research Design}

The study was designed according to the principles of action research. This qualitative research model allows teachers to observe their own teaching and to scrutinize a problem or action in a systematic way (McNiff, Lomax, \& Whitehead, 2004). This study aims to examine micro teaching sessions of preservice teachers. These sessions were video recorded, so the participants were able to watch their performances again and again. The instructor of the course watched teaching practices of preservice teachers, identified their mistakes and gave instant feedback accordingly. The data of the study were collected through video recordings and semi-structured interviews. The participants were also asked to keep learner diaries for data triangulation purposes. Semi-structured interviews were voice recorded as well. The participants signed consent form prior to the practice.

\subsection{Action Research Process}

It can be said that action research is triggered by a problem and continues until a sufficient amount of data regarding a solution to this specific problem is obtained. Mills (2003) defines action research process through the "dialectic action research cycle" below: 


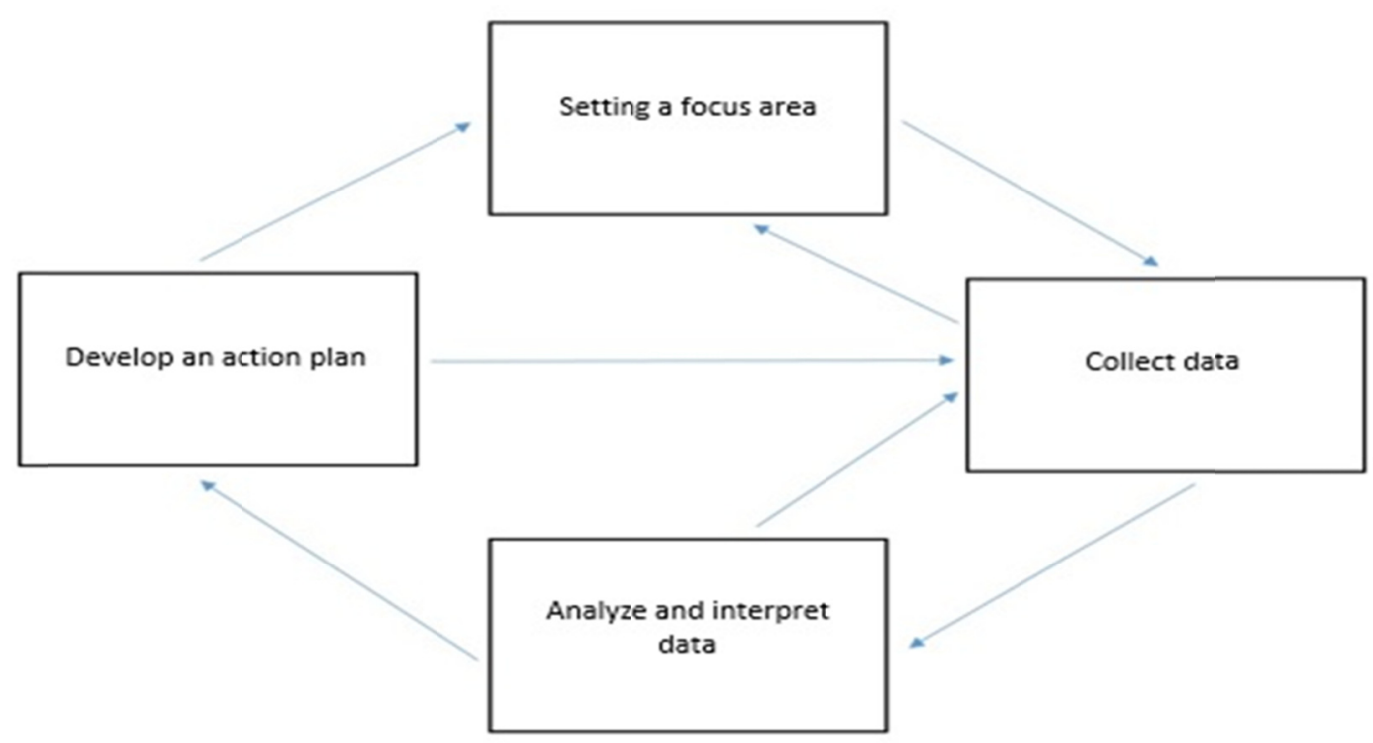

Figure 1. Action Research Process. Resource: Adapted from Mills (2003)

During the action research process, the plan is made, implemented and reorganized. Inappropriate or inoperative plans are reviewed. This cycle continues. In this study, this method was followed in the education of pre service teachers.

\subsection{Participants}

A total of 40 third year preservice teachers attending Physical Education and Sports Teaching Department of Kastamonu University School of Physical Education and Sport participated in the study; however, the data from 10 participants were used for the analysis. The real names of the participants were not used to ensure anonymity as suggested by research ethics principles.

\subsection{Data Collection Tools}

The study uses video recordings, semi-structured interviews and learner diaries as data collection instruments. Video recording of the practices allowed preservice teachers to realize their mistakes by watching them. For data triangulation purposes, the participants were asked to keep learner diaries, which were used in the data analysis later on. The questions to be asked in semi-structured interviews were prepared after a detailed literature review. Semi-structured interview form was finalized following the expert opinions (some questions were excluded from the form and the order of some questions changed). When the implementation phase ended, semi-structured interviews were conducted with preservice teacher in order to obtain their opinions about it.

\subsection{Implementation Phase}

The study was carried out throughout the Fall and the Spring terms of 2017-2018 academic year. In the first 7 weeks of each semester, the instructor provided theoretical information including lesson plan preparation (daily lesson plan). After the midterm exams, the students were divided into groups of 3 or 4 and later they realized micro teaching sessions approximately for 7 weeks for the predetermined branches (volleyball, korfball, dart, badminton, tennis, athletics, foot tennis, archery, folk dances, curling, step-aerobics, bowling etc.). At the end of each practice, the instructor gave instant feedback about micro teaching session. The lessons were video recorded, and participants were allowed to watch their performances. Moreover, semi-structured interviews were conducted in the instructor's office to obtain participants' opinions about the practices. The data obtained were transcribed and filed regularly. Because action research is a systematic process, so it is necessary to plan in advance which data to be collected (Johnson, 2005).

\section{Data Analysis and Interpretation}

Research data were analyzed through discourse analysis method, which is used to identify the presence of concepts, themes, words or sentences in one or more texts and later to tabulate these findings in figures (Kiziltepe, 2015). First of all, semi-structured interviews were transcribed regularly. The researcher and another academician checked the accuracy of these transcripts. Learner diaries were rewritten into Microsoft Word 
software regularly. When all the interviews were transcribed, the researcher determined codes and the themes related to these codes.

\section{Findings}

The findings were examined under four different themes: "implementation", "classroom management", "experience", and "lesson plan preparation".

\subsection{Findings Regarding the "Implementation" of Micro Teaching}

When we examine the students' opinions about micro teaching implementation, we can conclude that this practice has positive effects on them. The followings are examples of opinions that reflect these positive effects:

"Since we put theory into practice, realizing our mistakes and correcting them through real experiences resulted in higher retention. The practical part of the course taught me a lot skills such as how to establish rapport in the classroom and how to address to students. I also learned which method(s) to use in which phase of lessons." (S1)

"We learned how to plan our lessons, how to talk, what to pay attention for during teaching, and many more details like these. It was very helpful thanks to the supervising of our teacher. Now I'll go to the school (where I teach as part of "Teaching Practice course") and this knowledge helps me a lot. I establish better communication with my students, and I act more self-confidently since I know what to do. I believe that my teaching was positive." (S2)"

"Practice is very important for me. Because I have a good visual memory. I can't keep theoretical information in my memory well enough but when I see and practice something, it retains in my memory for a longer time (S3)".

"I believe we will teach better when we become a physical education and training teacher" (S7)."

"We learned about many teaching methods. If I hadn't taken that course, I would now find Teaching Practice course very challenging. Because I learned which teaching methods should be used when and how (S6)"

"We learned about practical methods in this course. I learned how to approach to students and how to make them interact with each other. I believe that this is the most important course in teaching training programs (S4)"

"Special Education Methods course has been beneficial for me a lot. I liked this course thanks to practical implementations. Because we focused on various sports branches. For instance, I found curling quite interesting. I learned how to address to students and how to teach (S5)" The opinions regarding this finding as reflected in learner diaries are as follows:

"At the beginning, I got anxious although the students I teach were my classmates. I even forgot how to give commands. But I started to take the control towards the middle of the lesson and the practice went better (LD, 06.04.2018)."

"Doing practical activities, teaching a lesson was more difficult than I guessed, but I did my best to overcome it (LD, 03.05.2018)".

Even short implementations can be said to contribute positively to students' professional developments and help them overcome anxiety.

\subsection{Findings Regarding "Classroom Management”}

The findings related to classroom management show that practical implementations have positive contributions to students' personal development. The opinions of students on this issue are as follows:

"We learned how to address to students and what we can or should do in certain situations (S2)".

"Up to now, I have met different types of students. We preferred punishment strategy when students did not stop talking. But I learned that this was a wrong strategy to apply, and it should not be applied directly. I will never use it when I become a teacher. I believe I will manage my classrooms better in the future (S8)"

"How should we address to our students, how will we teach and how will we talk in the classroom? This course was useful to find answers to these questions (S5)"

"Doing practices helped me a lot. I taught to my classmates. We were the teachers of the class that day. I learned how to start a lesson and to get students'attention. Let's say I lost the control in the lesson, I learned how to take the control of class and continue (S6)"

"Thanks to this course, I can correct my mistakes through my experiences and have a better classroom management" (S1)" 
The opinions stated in learners' diaries about this issue are as follows:

"Although the people I taught were my classmates, I found it difficult to manage the classroom, I even had to raise my voice sometimes. I was able to manage the classroom towards the end (LD15.05.2018)"

It might be stated that implementing practices in a course positively affects classroom management skills. The students were able to manage classroom better although they face some problems at the beginning.

\subsection{Findings Regarding "Experience"}

The following excerpts are about the findings related to "experience":

"It helped me gain experience because there are different types of students. It helped me to learn how I can deal with them, how I can teach and transfer my knowledge (S8)."

"It was beneficial a lot. I now know how I will give responsibility to my students, how I can make them be more active during the lesson and how I should behave" (S3)"

"I believe that I have gained experience. Since I know what to do, I feel more confident during teaching practice and I teach better and more efficiently (S2)."

"We are lucky to have practical implementation in this course, so we learn all the methods and techniques in a more detailed way in practice. We will teach better when we start teaching in real classrooms because these practices were like rehearsal of real teaching experiences. It was a great experience for us (S7)"

"I learned that I should take students in the center and guide them. For instance, I choose the methods that take students in the center, I believe that this implementation will work well in the future (S6)."

The learner diaries presented the following findings about "experience":

"Doing practices helped me gain experience in every aspect. I realized that being a good athlete is not so challenging but transferring knowledge to students required real talent. I learned how to teach and to address to students, so we will have no problem when I become a teacher (LD, 19.04.2018)"

"It worked very well in my Teaching Practice course sessions, I have taught confidently so far (LD, 12.04.2018)

The students' opinions and their diary entries show that integrating practical applications into this course positively contributed to their experiences.

\subsection{Findings Regarding "Lesson Plan Preparation"}

The following excerpts from semi-structured interviews reflect findings related to "preparing daily lesson plans":

"We learned how to prepare and apply lesson plans at school. Also, we realized the importance of making alternative plans and applying them when necessary (S4)"

"We learned that plans might be flexible, and they may not work all the time. For instance, there was a game activity, but the students failed to play the game. Later, I revised the game and played again. It increases our creativity too (S1)"

"I learned how to prepare lesson plans and what I should do. I realized my mistakes. I learned what I should do while teaching in the classroom or sports hall" (S2

"Right now, we are going to the school for Teaching Practice course. I did not know how to prepare lesson plans before this course. But I took the course and now I know how to do it. I am good at preparing them and they help me a lot in my lessons (S6)"

"I don't find it difficult to prepare lesson plans anymore (S5)".

The following learner diary entries present examples of ideas about "lesson plan preparation":

"Preparing a lesson plan and then teaching this lesson brings a great advantage. It is important to know what to do and when. I didn't know how to prepare lesson plans beforehand. It was really useful for Teaching Practice course (LD 21.03.2018)".

Preparing lesson plans and applying them in lessons can be said to contribute to the development of students.

\section{Discussion and Conclusion}

This study was conducted to develop teaching skills of preservice teachers attending the department of physical education and sports teaching, to help them realize when lesson plans (daily plans) fail and to teach them prepare alternative plans. What distinguishes practice from theory is that preservice teachers are gaining hands-on experience, experiencing real problems and suggesting solutions to these problems. Within the scope of the 
study, the students realized how important practice was and came up with solutions to the problems they encountered. It is believed that preservice teachers will be better equipped with theoretical and practical knowledge and be better teachers thanks to this implementation. Unfortunately, many preservice teachers receive only theoretical knowledge in Special Education Methods I -II courses; therefore, they often face problems when it is time for practice in real classrooms. Micro teaching method, as a popular method used in teacher training programs, is being used nowadays very often. There are many studies in the literature focusing on the use of micro teaching method with preservice teachers (Çakır, 2000; Görgen, 2003; Kuran, 2009; Semerci, 2011; Küçükoğlu et al., 2012; Karadağ \& Akkaya, 2013; Duban \& Fidan, 2015). The research findings revealed that micro teaching sessions which allowed preservice teachers to teach lessons under the conditions almost identical to real classrooms considerably contributed to their professional development. Most of the participants agreed with this idea. This finding is consistent with the study by Sevim (2013), which concluded that micro teaching helped preservice teachers prepare for lessons, present the content effectively and find solutions to problems encountered. Similarly, Karataş and Cengiz (2016) reached similar findings in their study. Another finding of the study is about "gaining experience". Accordingly, it was found that preservice teachers gained experience and learned about how to prepare for lessons and how to behave in classrooms thanks to micro teaching sessions. Gürses et.al (2005) found that "preservice teachers achieved sufficient levels of skills such as displaying the roles and the behaviors required by teaching profession and explaining the concepts", which is consistent with the finding of the study which stated that "preservice teachers' self-confidence increased and gained experience thanks to micro teaching sessions". These findings are in parallel with the finding of the study by Sevim (2013), which revealed that "micro teaching was effective in teaching preservice teachers about lesson presentations and finding solutions to the problems". The last finding of the study was about "preparing lesson plans". The study found that preservice teachers learned how to prepare and apply lesson plans thanks to micro teaching sessions. There are many studies supporting this finding in the literature. Özçelik (2017), in his study, concluded that preservice teachers of French gained experience in preparing lesson plans. Similarly, Gürses et al. (2005) found that preservice teachers were successful in preparing unit plans and daily lesson plans. In this study, physical education and sports teachers taking Special Education Methods I and II courses were given opportunities to practice their teaching and realize their mistakes and the skills they lack. In addition, micro teaching helped preservice teachers to improve themselves in terms of teaching practice, gaining experience, classroom management and lesson plan preparation, which is an important conclusion of the study.

\section{Recommendations}

Special Education Methods I-II courses might be offered in parallel with Teaching Practice courses so that preservice teachers can gain more experience in teaching.

\section{References}

Akyüz, H. İ., Pektaş, M., Kurnaz, M. A., \&Memiş, E. (2014). Akıllı Tahta Kullanımlı Mikro Öğretim Uygulamalarının Fen Bilgisi Öğretmen Adaylarının Tpab’larına ve Akıllı Tahta Kullanıma Yönelik Algılarına Etkisi. Cumhuriyet International Journal of Education, 3(1), 1-14. https://doi.org/10.30703/cije.321331

Arsal, Z. (2014). Mikro Öğretimin Öğretmen Adaylarının Sınıf Yönetimi Tutum ve İnançlarına Etkisi. Mersin Üniversitesi Ĕ̈itim Fakültesi Dergisi, 10(3), 137-150.

Atav, E., Kunduz, N., \& Seçken, N. (2014). Biyoloji Eğitiminde Mikro Öğretim Uygulamalarına Dair Öğretmen Adaylarının Görüşleri. Hacettepe Üniversitesi Eğitim Fakültesi Dergisi, 29(4), 1-15.

Bilen, K. (2014). Mikro Öğretim Tekniği İle Öğretmen Adaylarının Öğretim Davranışlarına İlişkin Algılarının Belirlenmesi. Erzincan Üniversitesi Eğitim Fakültesi Dergisi, 16(1), 181-203. https://doi.org/10.17556/jef.36672

Çakır, Ö. S. (2000). Öğretmen Yetiştirmede Teoriyi Pratiğe Bağlayan Mikro-Öğretimin Türkiye'deki Üç Üniversitede Durumu. Hacettepe Üniversitesi Eğitim Fakültesi Dergisi, 18, 62-68.

Çoban, A. (2015). Öğretmen Eğitiminde Mikro-Öğretim ve Farklı Yaklaşımlar. Elektronik Sosyal Bilgiler Dergisi, 14(53), 219-231. https://doi.org/10.17755/esosder.43863

Duban, N., \& Fidan, N. K. (2015). Öğretmen Adaylarının Mikro-Öğretim Uygulamalarına Bakışı. Uluslararası Sosyal Araştırmalar Dergisi, 8(41), 949-959. https://doi.org/10.17719/jisr.20154115076

Erciyeş, G. (2009). Öğretim Yöntem ve Teknikleri. İn: Öğretim İlke ve Yöntemleri (s. 277).

Fernandez, M. L. (2012). Learning through Microteaching Lesson Study in Teacher Preparation. Action in 
Teacher Education, 26(4), 37-47. https://doi.org/10.1080/01626620.2005.10463341

Görgen, İ. (2003). Mikroöğretim Uygulamasının Öğretmen Adaylarının Sınıfta Ders Anlatımına İlişkin Görüşleri. Hacettepe Üniversitesi Ĕ̈itim Fakültesi Dergisi, 24, 56-63.

Gürses, A., Bayrak, R., Yalçın, M., Açıkyıldız, M., \& Doğar, Ç. (2005). Öğretmenli Uygulamalarında Mikro Öğretim Yönteminin Etkililiğinin İncelenmesi. Kastamonu Ĕgitim Dergisi, 13(1), 1-10.

Johnson, A. P. (2005). A Short Guide to Action Research. USA: Pearson.

Karadağ, R., \& Akkaya, A. (2013). İlk Okuma Yazma Öğretimi Dersinde Mikro Öğretim Uygulamalarına İlişkin Öğretmen Adaylarının Görüşleri. Ahi Evran Üniversitesi Kırşehir Eğitim Fakültesi Dergisi, 14(2), 39-59. https://doi.org/10.17240/aibuefd.2014.14.1-5000091505

Karataş, Ö. F., \& Cengiz, C. (2016). Özel Öğretim Yöntemleri II Dersinde Gerçekleştirilen Mikro Öğretim Uygulamalarının Kimya Öğretmen Adayları Tarafından Değerlendirilmesi. Kastamonu Eğitim Dergisi, 24(2), 565-584.

Kızıltepe, Z. (2015). Nitel araştırma yöntem, teknik, analiz ve yaklaşımları. İçerik analizi (ss. 253-266). Ankara: Anı Yayınları.

Kuran, K. (2009). Mikro Öğretimin Öğretmenlik Meslek Bilgi ve Becerilerinin Kazanılmasına Etkisi. Mustafa Kemal Üniversitesi Sosyal Bilimler Enstitüsü Dergisi, 6(11), 384-401.

Küçükoğlu, A., Köse, E., Taşgın, A., Yılmaz, B. Y., \& Karademir, Ş. (2012). Mikro Öğretim Uygulamasının Öğretim Becerilerine Etkisine İliş̧kin Öğretmen Adayı Görüşleri. Eğitim Bilimleri Araştırmaları Dergisi, 2(2), 19-32.

Marulcu, İ., \& Dedetürk, A. (2014). Fen Bilgisi Öğretmen Adaylarının Mikro-Öğretim Yöntemini Uygulamaları: Bir Eylem Araştırması. Mustafa Kemal Universitesi Sosyal Bilimler Enstitüsü Dergisi, 11(25), 353-372.

Mcniff, J., Lomax, P., \& Whitehead, J. (2004). You and Your Action Research Project. London and New York: Hyde Publications. https://doi.org/10.4324/9780203612538

Mergler, A. G., \& Tangen, D. (2010). Using microteaching to enhance teacher efficacy in pre-service teachers. Teaching Education, 21(2), 199-210. https://doi.org/10.1080/10476210902998466

Mills, G. E. (2003). Action Research. A Guide for the Teacher Researcher. Upper Saddle River, NJ: Person Education, Inc.

Özçelik, N. (2017). Fransızca Okuma Becerisi Öğretiminde Mikro-Öğretim Uygulamalarına İlişkin Öğretmen Adaylarının Görüşleri. Hacettepe Üniversitesi Eğitim Fakültesi Dergisi, 32(1), 99-110. https://doi.org/10.16986/HUJE.2016022819

Peker, M. (2009). Genişletilmiş Mikro Öğretim Yaşantıları Hakkında Matematik Öğretmeni Adaylarının Görüşleri. Türk Eğitim Bilimleri Dergisi, 7(2), 353-376.

Semerci, Ç. (2011). Mikro Öğretim Uygulamalarının Çok-Yüzeyli Rasch Ölçme Modeli ile Analizi. Eğitim ve Bilim, 36(161), 14-24.

Sevim, S. (2013). Mikro Öğretim Uygulamasının Öğretmen Adayları Gözüyle Değerlendirilmesi. Dicle Üniversitesi Ziya Gökalp Eğitim Fakültesi Dergisi, 21, 303-313.

Şen, A. İ. (2009). A Study on the Effectiveness of Peer Microteaching in a Teacher Education Program. Education and Science, 34(151), 165-174.

Taşpınar, M. (2017). Kuramdan uygulamaya öğretim ilke ve yöntemleri. Pegem Atıf Indeksi, 1-387. https://doi.org/10.14527/9786052411032

\section{Copyrights}

Copyright for this article is retained by the author(s), with first publication rights granted to the journal.

This is an open-access article distributed under the terms and conditions of the Creative Commons Attribution license (http://creativecommons.org/licenses/by/4.0/). 